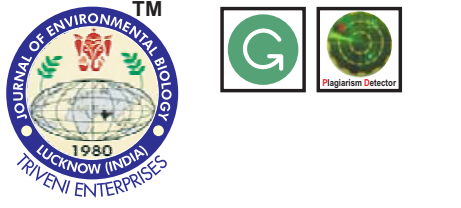

ISSN: 0254-8704 (Print)

\title{
Polyhydroxyalkanoates production by Zobellella species isolated from fish industrial effluents and its primary characterization
}

Authors Info

\section{S. Maity', S. Das ${ }^{2}$ and D.P. Samantaray ${ }^{1 *}$}

'Department of Microbiology, College of Basic Science \& Humanities, Orissa University of Agriculture and Technology, Bhubaneswar-751 003, India

${ }^{2}$ Department of Life Science, Laboratory of Environmental Microbiology and Ecology, National Institute of Technology, Rourkela- 769 008, India

*Corresponding Author Email : dpsamantaray@yahoo.com

Key words

Homopolymer Industrial effluent

Polyhydroxyalkanoates

Zobellela spp

Publication Info

Paper received: 08.12 .2016

Revised received : 26.02 .2017

Re-revised received: 14.04 .2017 Accepted : 24.06 .2017

\section{Abstract}

Aim : The present study aimed to produce and characterize polyhydroxyalkanoates by exploring high yielding bacterial isolates from fish industrial effluents.

Methodology : Industrial effluents samples were collected and processed for physico-chemical parameter and bacteriological analysis. The polyhydroxyalkanoates production efficacies of bacterial isolates were evaluated using submerged fermentation process and its primary characterization was carried out using fourier transform infra-red spectroscopy.

Results : Out of thirty three, five bacterial isolates showed accumulation of polyhydroxyalkanoates granule under Sudan black staining. These bacterial isolates were affiliated to genus Bacillus (DS1 and DH1), Aeromonas (DP1 and DI4) and Zobellella sp. DD5, based on morpho-physiological characterization. Under optimized condition, Zobellella sp. DD5 produced $2.2 \mathrm{~g} \mathrm{I}^{-1}$ polyhydroxyalkanoate from $3.0 \mathrm{~g}$ of dry cell biomass. The Fourier Transform Infra-Red Spectroscopy primary structural characterization study depict high intense peak at $1720.50 \mathrm{~cm}^{-1}$ corresponding to ester carbonyl $(C=0)$ stretching vibration of polyhydroxybutyrate, which is the most common homopolymer of polyhydroxyalkanoates.

Interpretation : This is the first report giving insight on non-growth associated polyhydroxybutyrate production $\left(2.2 \mathrm{gl}^{-1}\right)$ by Zobellella sp. DD5 under submerged fermentation process, and further structural and thermal characterization is highly indispensible for application of polyhydroxybutyrate.

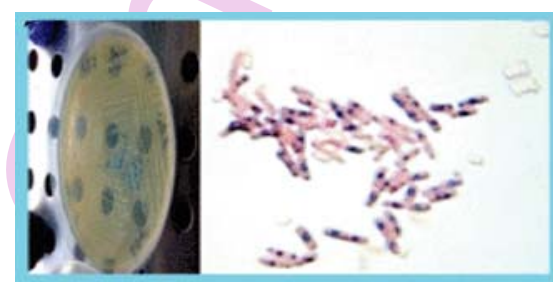

Accumulation of PHAs granules by Zobellella species DD5 isolated from fish industrial effluents.

Presence of ester carbonyl group $(\mathrm{C}=\mathrm{O})$ at $1720.50 \mathrm{~cm}^{-1}$ depict the biopolymer is PHB

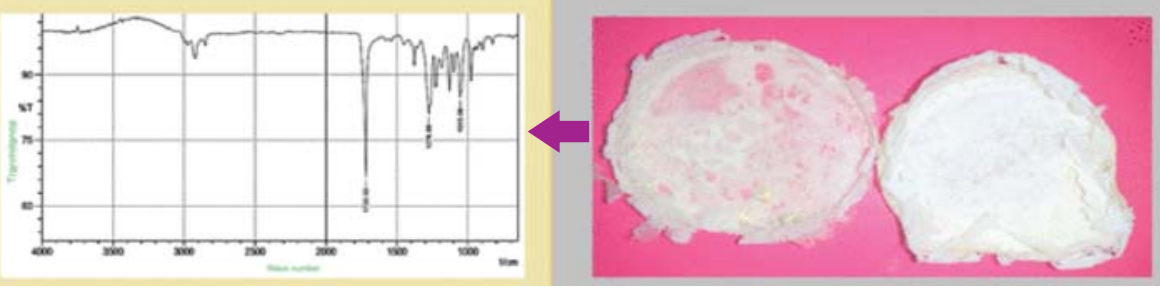




\section{Introduction}

Rapid progress in material science technology has produced plastic products with favorable mechanical integrity and excellent durability. Plastics have thus become an imperative part of our modern life style and are being used in different sectors. These are typically petroleum based nonbiodegradable synthetic polymers accumulated in the existing ecosystem, which have resulted in a huge burden towards plastic waste management (Chanprateep, 2010). However, it is very difficult to stop the use of plastic made items due to their versatile properties, but it is possible to replace petroleumbased plastics with an alternative biodegradable polymer that mimic properties of plastic. Among the various types of well known biodegradable plastics, polyhydroxyalkanoates are a type of biosynthetic and biodegradable biopolymer that decomposes into carbon dioxide and water. The endocellular polyhydroxyalkanoates are composed of biosynthesized hydroxy fatty acids and stored as lipid inclusions, when the carbon source is abundant, however other nutrients such as nitrogen, phosphorus, oxygen or sulfur are limited.

Accumulation of polyhydroxyalkanoates occurs adversely affected the microbes residing at different ecological niches such as estuarine sediments, marine habitat, rhizosphere, groundwater sediments, waste and sludge. These environments are often rich in organic content and less richer in nitrogen content enhances polyhydroxyalkanoates accumulation by microbes to meet the requirement of metabolic energy during carbon starvasion condition (Koller et al., 2011). The polyhydroxyalkanoates are synthesized by various Grampositive bacteria such as $B$. subtilis, $B$. amyloliquefaciens DSM7, $B$. licheniformis, $B$. macerans, $B$. cereus PS10, $B$. circulans, $B$. megaterium Y6, B. coagulans, B. brevis, B. thuringiensis, Clostridium sp., Corynebacterium sp., Nocardia sp., Rhodococcus sp., Streptomyces sp., Staphylococcus $s p$. and Gram-negative bacteria including Alcaligenes latus, Ralstonia eutropha, Aeromonas hydrophila, P. putida KT2440, P. oleovorans GP01, (Tortajada et al., 2013; Sharma and Bajaj, 2015 ). Moreover, V. harvey, V. fischeri and some haloarchea like Haloarcula sp. IRU1, Haloarculamaris mortui, Haloferax mediterranei (Singh et al., 2009; Poli et al., 2011) produce polyhydroxyalkanoates with different physical and chemical properties. The polyhydroxyalkanoates extracted from various bacteria are widely used as plastics materials, medical implants, drug delivery carriers, printing and photographic materials, nutritional supplements, drugs and fine chemicals (Chen, 2009). Wide-spread substitution of conventional plastics has been limited due to their high production cost, which holds back its successful commercialization (Waltz, 2008).

Thus, more efforts are needed for making this process economically feasible by analysing inherent mechanism of PHAs accumulation process and improving its productivity. In biotechnological terms, exploration of high PHAs yielding bacteria, inexpensive carbon sources, mutations and genetically modified high yielding bacteria can be used for biopolymer production (Yao et al., 2008). In light of the above, the present study focus towards polyhydroxyalkanoates production by exploring high yielding bacterial isolates from fish industrial effluent and its possible biomedical applications.

\section{Materials and Methods}

Isolation and screening of PHAs producing bacteria : Industrial effluent including waste-water and sediment samples were collected from the marine fish processing industries of Digha, West Bengal. The water and sediment samples were collected using sterile containers and processed in laboratory for physico-chemical parameter and bacteriological analysis. The chemicals and reagents used in the research work were procured from Sigma-Aldrich and Hi-Media Laboratories Pvt. Ltd. The aerobic, heterotrophic bacteria were isolated using Zobell marine agar medium employing serial dilution plate technique. The colonies of distinct morphological characters were individually picked up, sub-cultured and preserved in glycerol stock at $-80^{\circ} \mathrm{C}$ for further use. Prior to screening, the isolates were induced to accumulate polyhydroxyalkanoates granule in their cytosol using nitrogen limiting medium $\left(\mathrm{NaCl} 3.0, \mathrm{KH}_{2} \mathrm{PO}_{4} 1.5, \mathrm{~K}_{2} \mathrm{HPO}_{4}\right.$ 1.5, $\mathrm{MgSO}_{4} .5 \mathrm{H}_{2} \mathrm{O} 1.0$, glucose 10.0 , ammonium chloride 0.5 and agar agar $15.0 \mathrm{~g} \mathrm{l}^{-1}$ ) and incubated at $37^{\circ} \mathrm{C}$ for $48 \mathrm{hr}$. Bacterial isolates were then subjected to Sudan black staining (Schlegel et al., 1970) followed by viable colony technique such as Nile-red staining (Spiekermann et al., 1999) for confirmation of intercellular polyhydroxyalkanoates granule.

Morpho-physiological characterization : The morphophysiological characteristics of polyhydroxyalkanoates accumulating bacterial isolates were investigated by their colony morphology on Zobell marine agar and Gram's reactions with light microscopic observations. Bacterial isolates were then processed for generic level identification by the standard methods of biochemical, enzymatic, sugar utilization and antibiotic sensitivity tests as prescribed by Bergy's Manual of Determinative Bacteriology (Holt et al., 1994).

Optimization of growth parameters using one factor at a time (OFAT) approach : Several growth factors such as culture medium, $\mathrm{pH}$, temperature, $\mathrm{NaCl}$, carbon source, nitrogen source and inoculums size were optimized by standard OFAT method. Briefly, the day old inoculum containing $1.5 \times 10^{8}$ cells $\mathrm{ml}^{-1}$ (0.5 McFarland standards) were inoculated to modified growth medium and phosphate buffer saline medium and incubated at $37^{\circ} \mathrm{C}$ for $24 \mathrm{hrs}$. The biomass production was compared by taking weight of cell pellets obtained after centrifugation. Correspondingly, other parameters comprised $\mathrm{pH}(4-10)$, temperature $\left(23-44^{\circ} \mathrm{C}\right)$, salt concentration $(1-6 \%$ $\mathrm{w} / \mathrm{v}$ ), carbon (glucose, dextrose, glycerol, lactose, sucrose and arabinose) and nitrogen sources $\left(\mathrm{NH}_{4}\right)_{2} \mathrm{SO}_{4}, \mathrm{NH}_{4} \mathrm{NO}_{3}, \mathrm{NH}_{4} \mathrm{Cl}$, urea and yeast extract) in a constant ratio (6:1) and inoculum size $(5-20 \% \mathrm{v} / \mathrm{v})$. Bacterial biomass was then estimated by measuring the $\mathrm{OD}_{600}$ by a UV-Vis spectrophotometer $(\lambda 35$, 


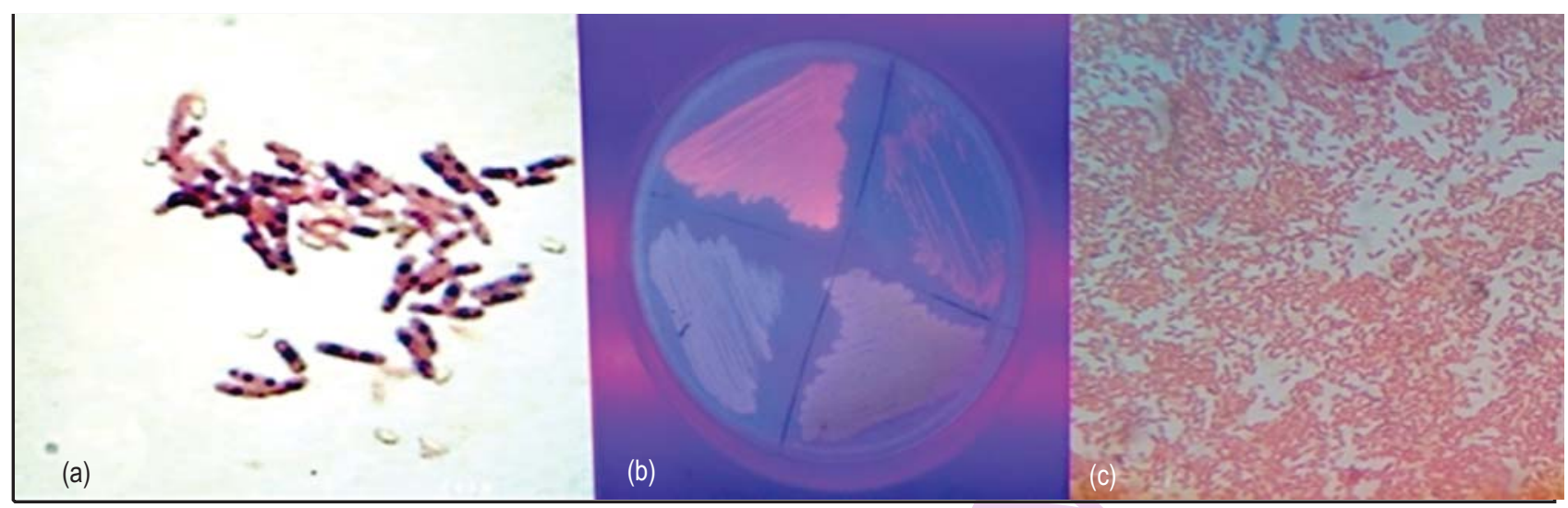

Fig. 1 : (a) Sudan black stain (b) Nile red stain (c) Gram stain image of the Zobellella sp. DD5

\section{Perkin-Elmer).}

Polyhydroxyalkanoates production under submerged fermentation and quantitative analysis : Polyhydroxyalkanoates production was carried out in the modified growth media using submerged fermentation processes. Under optimized conditions, one-stage batch cultivation in shake flasks method was conducted for polyhydroxyalkanoates production using bacterial isolates. In nutshell, the bacterial isolates were grown in 1 liter of growth medium for 72 hrs at $37^{\circ} \mathrm{C}$. Cell biomass was then harvested by centrifugation at $10,000 \mathrm{rpm}$ for $10 \mathrm{~min}$ and kept for drying. Subsequently, polyhydroxyalkanoates extraction was accomplished by sodium hypochlorite digestion and multi-solvent extraction process. Finally, the polyhydroxyalkanoates were dissolved in boiling chloroform and subsequent evaporation to yield polyhydroxyalkanoates. The polyhydroxyalkanoates production was also quantified by standard formula.

Fourier transform infrared spectroscopy analysis : The presence of functional groups in the extracted polyhydroxyalkanoates was determined by Fourier transform infrared spectroscopy. About $1 \mathrm{mg}$ of PHAs sample was mixed with $2 \%(\mathrm{w} / \mathrm{w})$ potassium bromide and compressed into translucent sample discs and fixed in the Fourier transform infrared spectrometer (Perkin-Elmer RX I). Scanning was performed under the following conditions: spectral range, $4000-400 \mathrm{~cm}^{-1}$; window material, Csl; 16 scans; resolution $4 \mathrm{~cm}^{-1}$. The detection was conducted with a temperature stabilized, coated FR-DTGS detector.

\section{Results and Discussion}

The physico-chemical parameters of a sampling site always impose high impact on the bacterial population. Thus pH, temperature and salinity of waste-water and sediment samples were analyzed and were found to be $7.82-8.29,36-39^{\circ} \mathrm{C}$ and $15.2-$ $25.4 \mathrm{ppt}$, respectively. Out of thirty three bacterial isolates, five bacterial isolates showed accumulation of polyhydroxyalkanoates granule in their cytosol as confirmed by Sudan black followed by Nile red staining (Fig. 1a and 1b). Based on the Gram's reaction, morphological features and biochemical tests, the bacterial isolates belonged to genus Bacillus (DS1 and DH1) and Aeromonas (DP1 and D(4). These bacterial isolates were able to produce different extracellular enzymes like gelatinase, lipase, amylase, caseinase, cellulase and pectinase and utilized various sugars used in the study. Interestingly, the isolate DD5 depicted distinct morphophysiological properties such as Gram-negative rods (Fig. 1c), nonspore forming, motile, facultative anaerobes, oxidase, catalase, gelatinase, lipase and amylase positive, grew at $30-37^{\circ} \mathrm{C}, \mathrm{pH} 7-8$, salt concentration $1-3 \%(\mathrm{w} / \mathrm{v})$ and able to ferment glucose, cellobiose, maltose, melibiose, trehalose, starch, mannitol, sorbitol and found to be the member of genus Zobellella (Lin and Shieh, 2006). In contrast, to the observations made in the present study, the polyhydroxyalkanoates producing different species of Bacillus, Zobellella and Aeromonas have been reported from various environments such as waste-water, sewage and sludge ecosystems, respectively (Mohapatra et al., 2015; Ibrahim and Stinbuchel, 2009; Kung et al., 2007). Moreover, waste and wastewaters have high biological oxygen demand and chemical oxygen demand values as compared to other ecological niches and rich in organic contents and less in nitrogen and phosphorus (Bhuwal et al., 2013). This unbalanced nutrient status (carbon: nitrogen) creates selective pressures (Mohapatra et al., 2016; Wang and Bakken, 1998) which may play a major role in accumulation of polyhydroxyalkanoates granules in the cytosol of bacteria.

The growth parameters play a key role on biomass production as well as synthesis of polyhydroxyalkanoates in vitro. Optimization study revealed that maximum amount of biomass was obtained in modified growth medium than phosphate buffered saline medium. Thus, biomass production of screened bacterial isolates were optimized in modified growth medium and observed that $\mathrm{pH} 8.0$, temperature $37^{\circ} \mathrm{C}, \mathrm{NaCl}$ concentration $2 \%$, carbon and nitrogen source (glucose and ammonium sulphate) and inoculum size $15 \%$ were optimum at $P<0.05$ significance level (Fig. 2a, b, c, d, e and f) (Mohapatra et al., 2014; Ray et al., 2016). Under optimized conditions, Zobellella sp. DD5 was found to produce maximum amount of polyhydroxyalkanoates $\left(2.2 \mathrm{gl}^{-1}\right)$ from $3.0 \mathrm{~g}$ dry cell biomass in modified growth medium than other 


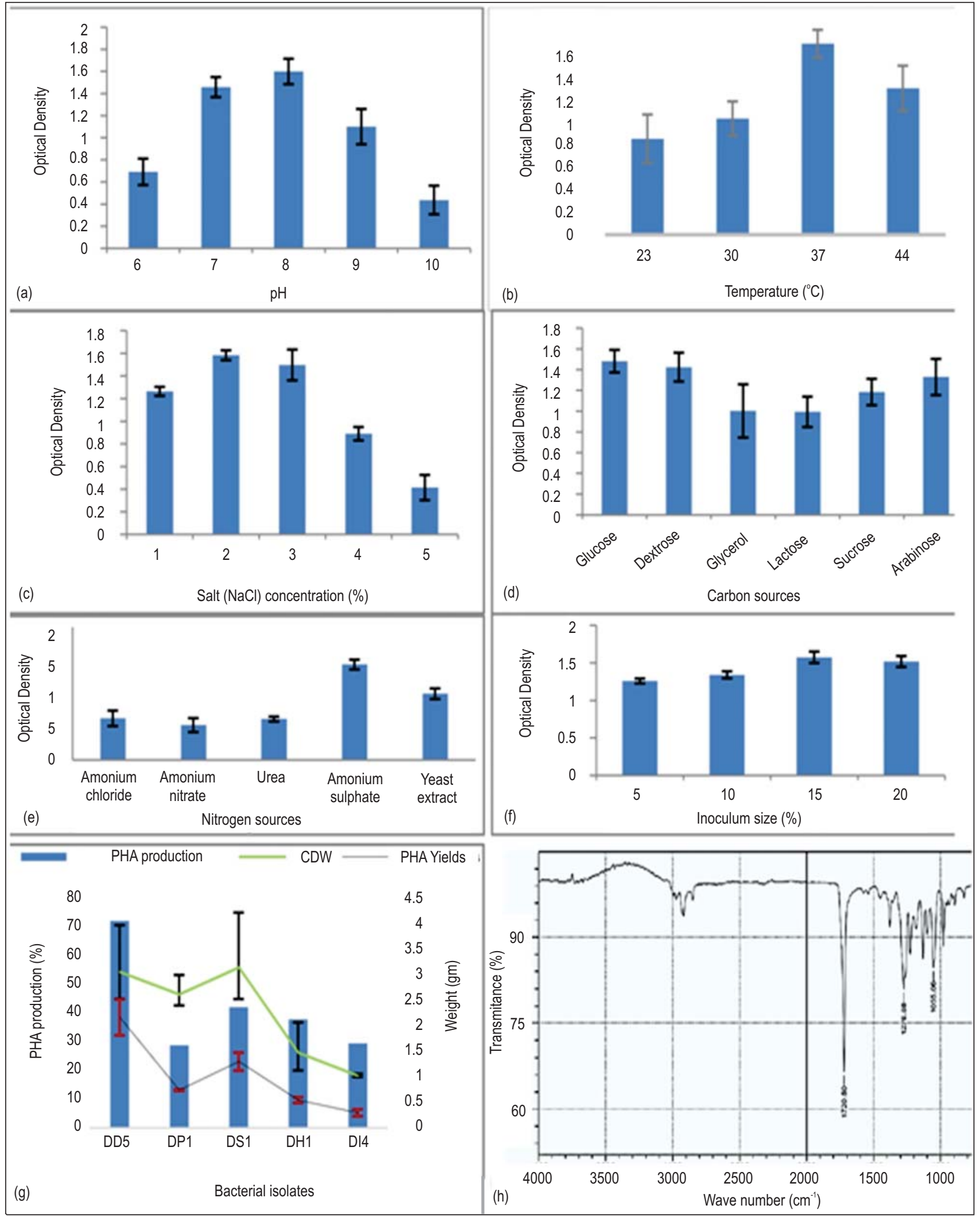

Fig. 2 : Optimization of growth parameter of polyhydroxyalkanoates producing bacterial isolates : (a) pH; (b) Temperature; (c) NaCl concentrations; (d) Carbon sources; (e) Nitrogen sources; (f) Inoculum size; (g) Polyhydroxyalkanoates production by bacterial isolates under optimized condition and (h) FTIR analysis of the extracted polyhydroxyalkanoates 
bacterial isolates (Fig. 2g). This is the first report giving insight on non-growth associated polyhydroxyalkanoates production by Zobellella species. However, growth associated polyhydroxybutyrate production of $4.30 \mathrm{~g} \mathrm{I}^{-1}$ at $5.15 \mathrm{~g} \mathrm{l}^{-1}$ dry cell biomass by Z. denitrificans MW1 using glycerol as carbon source has been reported by Ibrahim and Steinbuchel (2010). In addition, $0.413 \mathrm{~g} \mathrm{l}^{-1}$ and $0.48 \mathrm{~g} \mathrm{l}^{-1}$ of polyhydroxyalkanoates were also produced by the related genera of Zobellella such as Oceanimonas and Aeromonas by non-growth associated mechanism (Ramezani et al., 2015; Chien and Ho, 2008). The primary structural characterization of extracted polyhydroxyalkanoates showed (Fig. 2h) distinct peak at 1055.06 $\mathrm{cm}^{-1}$ (C-N stretch) and $1276.88 \mathrm{~cm}^{-1}$ (C-C, C-H, O-H stretch). However, high intense peak was obtained at $1720.50 \mathrm{~cm}^{-1}$ corresponding to ester carbonyl $(\mathrm{C}=0)$ stretching vibration of polyhydroxybutyrate. The fourier transform infrared spectroscopy analysis depicted correct insight for the chemical structure of polyhydroxybutyrate, which is the most common homo-polymer of polyhydroxyalkanoates. This result is similar to the IR spectrum obtained at $1720.50 \mathrm{~cm}^{-1}$ corresponding to $(\mathrm{C}=0)$ ester carbonyl group, characteristics of polyhydroxybutyrate produced by Zobellella species (Maity et al., 2017). Moreover, the presence of ester carbonyl group at $1721.95 \mathrm{~cm}^{-1}, 1634.7 \mathrm{~cm}^{-1}$ and $1720 \mathrm{~cm}^{-1}$ were also observed in polyhydroxybutyrate extracted from Bacillus cereus, Bacillus subtilis and Bacillus licheniformics (Sharma and Bajaj, 2015; Muralidharan and Radha, 2015; Shah, 2012; Preethi et al., 2012).

It can be concluded that Zobellella sp. DD5 produced 2.2 $\mathrm{g} \mathrm{I}^{-1}$ of polyhydroxybutyrate under submerged fermentation process and further structural characterization is highly indispensible for possible agricultural and biomedical applications. This study exploits a new insight for the unexplored Zobellella species for polyhydroxybutyrate production.

\section{Acknowledgment}

The authors are grateful to the Head, Department Microbiology and Central Laboratory, OUAT, Bhubaneswar for providing facilities for completion of this work. The authors have no conflict of interest to declare.

\section{References}

Bhuwal, A.K., G. Sing, N.K. Aggarwal, V. Goyal and A. Yadav: Isolation and screening of polyhydroxyalkanoates producing bacteria from pulp, paper, and cardboard industry waste. Int. J. Biomat., (2013), doi:10.11555/2013/752821.

Chanprateep, S.: Current trends in biodegradable polyhydroxyalkanoates. J. Biosci. Bioeng., 110, 621-632 (2010).

Chen, G.Q.: A microbial polyhydroxyalkanoates (PHA) based bio- and materials industry. Chem. Soc. Rev., 38, 2434-2446 (2009).

Chien, C.C. and L.Y. Ho: Polyhydroxyalkanoates production from carbohydrates by a genetic recombinant Aeromonas sp. Lett. Appl. Microbiol., 47, 587-593 (2008).

Holt, J., N. Krieg, P. Sneath, J. Staley and S. Williams: Bergey's Manual of Determinative Bacteriology. Williamson and Wilkins (1994).
Ibrahim, M.H.A. and A. Steinbuchel : Poly (3-Hydroxybutyrate) production from glycerol by Zobellella denitrificans MW1 via highcell-density fed-batch fermentation and simplified solvent extraction. Appl. Environ. Microbiol., 75, 6222-6231 (2009).

Ibrahim, M.H.A. and A. Steinbuchel: Zobellella denitrificans strain MW1, a newly isolated bacterium suitable for poly(3-hydroxybutyrate) production from glycerol. J. Appl. Microbiol., 108, 214-225 (2010).

Koller, M., P. Hesse, A. Salerno, A. Reiterer and G. Braunegg: A viable antibiotic strategy against microbial contamination in biotechnological production of polyhydroxyalkanoates from surplus whey. Biomass Bioenergy, 35, 748-753 (2011).

Kung, S.S., Y.C. Chuang, C.H. Chen and C.C. Chien: Isolation of polyhydroxyalkanoates-producing bacteria using a combination of phenotypic and genotypic approach. Lett. Appl. Microbiol., 44, 364-371 (2007).

Lin, Y.T. and W.Y. Shieh: Zobellella denitrificans gen. nov., sp. nov. and Zobellella taiwanensis sp. nov., denitrifying bacteria capable of fermentative metabolism. Int. J. Syst. Evol. Microbiol., 56, 12091215 (2006).

Maity, S., S. Das and D.P. Samantaray: Effect of vitamin on accumulation of PHB by Zobellella species under submerged fermentation process. Int. J. Curr. Microbiol. App. Sci., 6, 1310-1316 (2017).

Mohapatra, S., D.P. Samantaray and S.M. Samantaray: Phylogenetic heterogeneity of the rhizospheric soil bacterial isolates producing PHAs revealed by comparative analysis of $16 \mathrm{~s}-\mathrm{rRNA}$. Int. J. Curr. Microbiol. App. Sci., 3, 680-690 (2014).

Mohapatra, S., D.P. Samantaraya, S.M. Samantaraya, B.B. Mishra, S. Das, S. Majumdar, S.K. Pradhan, S.N. Rath, C.C. Rath, J. Akhtar and K.G. Acharya: Structural and thermal characterization of PHAs produced by Lysinibacillus $\mathrm{sp}$. through submerged fermentation process. Int. J. Biol. Macromol., 93, 1161-1167 (2016).

Mohapatra, S., P.R. Mohanta, B. Sarkar, A. Daware, C. Kumar and D. P. Samantaray: Production of polyhydroxyalkanoates (PHAs) by Bacillus strain isolated from waste water and its biochemical characterization. Proc. Natl. Acad. Sci., India, Sect. B Biol. Sci., (2015), doi:10.1007/s40011-015-0626-6.

Muralidharan, R. and K.V. Radha: A kinetic study of polyhydroxybutyrate production on nitrogen limited medium using Bacillus subtilis MTCC 9763 through a two stage cultivation strategy. J. Environ. Biol., 36, 537-542(2015).

Poli, A., P.D. Donato, G.R. Abbamondi and B. Nicolaus: Synthesis, production, and biotechnological applications of exopolysaccharides and polyhydroxyalkanoates by archaea. Archaea, 2011, doi:10.1155/2011/693253.

Preethi, R., P. Sasikala and J. Aravind: Microbial production of polyhydroxyalkanoate (PHA) utilizing fruit waste as a substrate. Res. Biotech., 3, 61-69 (2012).

Ramezani, M., M.A. Amoozegar and A. Ventosa: Screening and comparative assay of poly-hydroxyalkanoates produced by bacteria isolated from the Gavkhooni Wetland in Iran and evaluation of poly- $\beta$-hydroxybutyrate production by halotolerant bacterium Oceanimonas sp. GK1. Ann. Microbiol., 65, 517-526 (2015).

Ray, S., V. Prajapati, K. Patel and U. Trivedi: Optimization and characterization of PHAs from isolate Pannonibacter phragmitetus ERC8 using glycerol waste. Int. J. Bio. Macromol., 86, 741-749 (2016).

Schlegel, H.G., R. Latterty and I. Krauss: Isolation of mutants not accumulating polyhydroxy butyric acid. Arch. Microbiol., 71, 283-94 (1970).

Shah, K.R.: FTIR analysis of polyhydroxyalkanoates by novel Bacillus 
sp. AS 3-2 from soil of Kadi region, North Gujarat, India. J. Biochem. Techn., 3, 380-383 (2012).

Sharma, P. and B.K. Bajaj: Cost-effective substrates for production of poly- $\beta$ - hydroxybutyrate by a newly isolated Bacillus cereus PS10. J. Environ. Biol., 36, 1297-1304 (2015).

Singh, M., S.K.S. Patel and V.C. Kalia: Bacillus subtilis as potential producer for polyhydroxyalkanoates. Microbial Cell Fact., 8, 38 (2009).

Spiekermann, P., B.H.A. Rehm, R. Kalscheuer, D. Baumeister and A. Steinbüchel: A sensitive, viable-colony staining method using Nile red for direct screening of bacteria that accumulate polyhydroxy alkanoic acids and other lipid storage compounds. Arch. Microbiol., 171, 73-80(1999).
Tortajada, M., L.F. Silva and M.A. Prieto : Second-generation functionalized mediumchainlength polyhydroxyalkanoates: the gateway to high-value bioplastic applications. Int. J. Microbiol., 16, $1-15(2013)$

Waltz, E. : Do biomaterials really mean business?. Nat. Biotech., 26, 851 853 (2008).

Wang, J. and L.R. Bakken: Screening of soil bacteria for poly- $\beta$ hydroxybutyric acid production and its role in the survival of starvation. Microb. Ecol., 35, 94-101 (1998).

Yao, Y.C., X.Y. Zhan, J. Zhang, X.H. Zou, Z.H. Wang and Y.C. Xiong : A specific drug targeting system based on polyhydroxyalkanoate granule binding protein PhaP fused with targeted cell ligands. Biomaterials, 29, 4823-4830 (2008). 